\title{
UPTAKE OF NERVE GROWTH FACTOR ALONG PERIPHERAL AND SPINAL AXONS OF PRIMARY SENSORY NEURONS ${ }^{1}$
}

\author{
P. M. RICHARDSON ${ }^{2}$ AND R. J. RIOPELLE \\ Division of Neurosurgery, McGill University, Montreal, Canada, and Division of Neurology, Queen's University, \\ Kingston, Canada
}

Received August 22, 1983; Revised January 13, 1984; Accepted January 13, 1984

\begin{abstract}
To investigate the distribution of nerve growth factor (NGF) receptors on peripheral and central axons, $\left[{ }^{125}\right.$ I]NGF was injected into the sciatic nerve or spinal cord of adult rats. Accumulation of $\left[{ }^{125} \mathrm{I}\right] \mathrm{NGF}$ in lumbar dorsal root ganglia was monitored by gamma emission counting and radioautography.

[ $\left.{ }^{125} \mathrm{I}\right]$ NGF, injected endoneurially in small quantities, was taken into sensory axons by a saturable process and was transported retrogradely to their cell bodies at a maximal rate of 2.5 to $7.5 \mathrm{~mm} / \mathrm{hr}$. Because very little $\left[{ }^{125} \mathrm{I}\right] \mathrm{NGF}$ reached peripheral terminals, the results were interpreted to indicate that receptors for $\mathrm{NGF}$ are present on nonterminal segments of sensory axons. The specificity and high affinity of NGF uptake were illustrated by observations that negligible amounts of gamma activity accumulated in lumbar dorsal root ganglia after comparable intraneural injection of $\left.{ }^{125} \mathrm{I}\right]$ cytochrome C or ${ }^{125}$ I] oxidized NGF.

Similar techniques were used to demonstrate avid internalization and retrograde transport of $\left[{ }^{125} \mathrm{I}\right]$ NGF by intraspinal axons arising from dorsal root ganglia. Following injection of $\left[{ }^{125} \mathrm{I}\right] \mathrm{NGF}$ into lumbar or cervical regions of the spinal cord, neuronal perikarya were clearly labeled in radioautographs of lumbar dorsal root ganglia.

Sites for NGF uptake on primary sensory neurons in the adult rat are not restricted to peripheral axon terminals but are extensively distributed along both peripheral and central axons. Receptors on axons provide a mechanism whereby NGF supplied by glia could influence neuronal maintenance or axonal regeneration.
\end{abstract}

Nerve growth factor (NGF) is necessary for the development and function of sensory neurons (Gorin and Johnson, 1979, 1980; Kessler and Black, 1980; Goedert et al., 1981; Schwartz et al., 1982; Otten and Lorez, 1983); $\mathrm{NGF}$, or a similar molecule, is released by Schwann cells or other cells that are present within peripheral nervo trunks (Burnham et al., 1972; Riopelle et al., 1981; Richardson and Ebendal, 1982). If NGF-like activity of endoneurial origin is physiologically important (Varon and Bunge, 1978), receptors for NGF are to be expected in axonal membrane along the course of peripheral sensory fibers. In previous studies of axonal internalization and retrograde transport of $\left.{ }^{125} \mathrm{I}\right] \mathrm{NGF}$ in vivo (Iendry et al., 1974; Stoeckel et al., 1975; Johnson et al., 1978; Dumas

\footnotetext{
${ }^{1}$ This work was supported by the Medical Research Council of Canada and the Multiple Sclerosis Society of Canada. We wish to thank Valerie Issa, Monica Altares, and Shizuye Faulkner for technical assistance and Evelyn Domond for secretarial assistance.

${ }^{2}$ To whom correspondence should be addressed, at Division of Neurosurgery, Montreal General Hospital, 1650 Cedar Avenue, Montreal, Canada, H3G $1 \mathrm{~A} 4$.
}

et al., 1979), uptake has been demonstrated at or near peripheral sympathetic and sensory terminals, but the possible existence of receptors on more proximal axonal segments has not been examined systematically. In vitro, $\left[{ }^{125} \mathrm{I}\right] \mathrm{NGF}$ has been shown by radioautography to bind to cell bodies, neurites, and neurite terminals of cultured sympathetic and dorsal root ganglion neurons (Kim et al., 1979; Carbonetto and Stach, 1982; Rohrer and Barde, 1982). From observations of $\left[{ }^{125} \mathrm{I}\right] \mathrm{NGF}$ uptake and transport in adult rats, we conclude that specific receptors for $\mathrm{NGF}$ are found on peripheral sensory axons within the sciatic nerve and also on spinal axons of primary sensory neurons.

\section{Materials and Methods}

Preparation of $\left[{ }^{125} I\right] N G F$. NGF was prepared from submandibular glands of male Swiss-Webster mice (Jackson Laboratories) according to the method of Mobley et al. (1976) with substitution of a continuous gradient of $\mathrm{NaCl}$ concentration for the last elution (Chapman et al., 1981). In bioassay with dissociated chick 
sensory neurons (Riopelle and Cameron, 1981), maximal neurite outgrowth was obtained at approximately $70 \mathrm{pg}$ / $\mathrm{ml}$ of NGF. For radioiodination (Sutter et al., 1979), a mixture of $\mathrm{NaI}(5 \mu \mathrm{Ci}$, Amersham Searle), NGF $(5 \mu \mathrm{g})$, hydrogen peroxide $(5 \mu \mathrm{l}$ of a $0.003 \%$ solution at 0 and 30 min), and phosphate buffer $(0.1 \mathrm{M}, \mathrm{pH} 7.4$ to a total volume of $50 \mu \mathrm{l}$ ) were incubated for $1 \mathrm{hr}$ at room temperature. Fifty microliters of cold $0.4 \%$ acetic acid and 200 to $400 \mu \mathrm{l}$ of acetate buffer $(0.5 \mathrm{M}, \mathrm{pH} 4.0)$ with bovine serum albumin $(1 \mathrm{mg} / \mathrm{ml})$ and protamine sulfate $(1 \mathrm{mg} / \mathrm{ml})$ were then added, and the mixture was dialyzed for 36 to $48 \mathrm{hr}$ against two or three changes of $0.05 \mathrm{M}$ acetate buffer ( $\mathrm{pH} 4.0$ ). The efficiency of labeling was 50 to $65 \%$, and after dialysis $>95 \%$ of gamma activity was precipitable with $10 \%$ trichloroacetic acid. Six preparations of $\left[{ }^{125} \mathrm{I}\right] \mathrm{NGF}$ from two batches of NGF were used with final concentrations of 10 to $38 \mathrm{ng} / \mu \mathrm{l}$ and specific activities of 34 to $84 \mathrm{cpm} / \mathrm{pg}$ (approximately 30 to 80 $\mu \mathrm{Ci} / \mu \mathrm{g})$. For dose-response curves, $\left[{ }^{125} \mathrm{I}\right] \mathrm{NGF}$ was diluted with saline or mixed with unlabeled NGF, and final concentrations were verified with gamma counting. $\mathrm{Cy}$ tochrome C (Sigma Chemical Co.) and NGF with two oxidized tryptophan residues (Cohen et al., 1980) were also radioiodinated by the lactoperoxidase technique. The final concentrations and specific activities were 12 $\mathrm{ng} / \mu \mathrm{l}$ and $18 \mathrm{cpm} / \mathrm{pg}$ for $\left[{ }^{125} \mathrm{I}\right]$ cytochrome $\mathrm{C}$ and $11 \mathrm{ng} /$ $\mu \mathrm{l}$ and $14 \mathrm{cpm} / \mathrm{pg}$ for $\left[{ }^{125} \mathrm{I}\right]$ oxidized NGF. Iodinated proteins were injected within 2 weeks of preparation.

Injections. Female Sprague-Dawley rats weighing 150 to $200 \mathrm{gm}$ (Charles River Breeding Labs) were anesthetized with pentobarbital, and the sciatic nerve was exposed in the thigh. Through a glass micropipette connected to a Hamilton syringe and filled with mineral oil (Beitz and King, 1976), $1 \mu$ l of a given solution was injected into the sciatic nerve near the origin of the nerve to biceps femoris. In control experiments, injection was, if necessary, further distal, and the sciatic nerve was crushed with jeweller's forceps either at the site of injection or 1.0 to $2.0 \mathrm{~cm}$ proximally. In two instances, the tibial, peroneal, sural, and biceps branches of the sciatic nerve were all cut at the time of injection to prevent $\left[{ }^{125} \mathrm{I}\right] \mathrm{NGF}$ from reaching sensory axon terminals.

For intraspinal injections, laminectomies were performed with microsurgical technique at high cervical or high lumbar levels. After subdural injection of paraffin oil to prevent extravasation in the CSF, $\left[{ }^{125}\right.$ I] NGF (or another ${ }^{125} \mathrm{I}$-protein) was injected in two to four sites to a total volume of 2 to $4 \mu \mathrm{l}$.

Counting of gamma activity. Four to $24 \mathrm{hr}$ after injection of $\left[{ }^{125} \mathrm{I}\right] \mathrm{NGF}$, rats were anesthetized and perfused with $4 \%$ formaldehyde, $0.5 \%$ glutaraldehyde in phosphate buffer. The fourth and fifth lumbar dorsal root ganglia (L4 and L5 DRG), identified by reference to the sacrum, were removed, and their gamma emission was counted in an LKB-Wallac 1270 Rackgamma counter.

SDS-polyacrylamide gel electrophoresis. Twelve L4 or L5 DRG, collected $10 \mathrm{hr}$ after intraneural administration of $\left[{ }^{125} \mathrm{I}\right] \mathrm{NGF}$, were homogenized in an aqueous solution of $1 \% \mathrm{SDS}$ and $2 \% \beta$-mercaptoethanol. The homogenate was concentrated to $0.3 \mathrm{ml}$ by evaporation, heated to $100^{\circ} \mathrm{C}$ for $5 \mathrm{~min}$, and centrifuged. Fifty-microliter aliquots of the supernatant were electrophoresed with a discontinuous buffer system (Laemmli, 1970) and resolving gel containing $12 \%$ polyacrylamide and $0.1 \%$ SDS. Each lane of the gel was cut into $10-\mathrm{mm}$ slices which were counted individually.

Radioautography. Selected DRG were fixed, osmicated, dehydrated, and embedded in plastic. Sections, $1 \mu \mathrm{m}$ thick, were dipped in Kodak NTB-2 emulsion, stored in lightproof boxes for 1 month, developed with Kodak D19 solution, stained with toluidine blue, and mounted in glycerine.

\section{Results}

One hour after injection of $\left[{ }^{125} \mathrm{I}\right] \mathrm{NGF}(1 \mu \mathrm{l}, 8 \mathrm{ng})$ into the sciatic nerve, $97 \%$ of the activity within the nerve was contained in a segment $1 \mathrm{~cm}$ long; at $12 \mathrm{hr}, 96 \%$ of the intraneural activity (35\% of the injected activity) was recuvered in a $3.5 \mathrm{~cm}$ segment of nerve (Fig. 1). These data delineate limits for diffusion of $\left[{ }^{125} \mathrm{I}\right] \mathrm{NGF}$ within the nerve.

Eight or more hours after injection of $\left[{ }^{125} \mathrm{I}\right] \mathrm{NGF}$ into the sciatic nerve, significant gamma activity was consistently detected in ipsilateral L4 and L5 DRG (Fig. 2a). Small and variable amounts of gamma activity were also counted in L3 and L6 ganglia, but none was found in the lumbar spinal cord. Neither crushing the nerve at the site of injection nor isolating the nerve from its peripheral connections by sectioning distal branches changed the accumulation of activity in L4 and L5 DRG. Nerve crush 1.5 to $2.0 \mathrm{~cm}$ proximal to the injection site completely prevented gamma activity from reaching lumbar DRG (T'able 1); crush $1.0 \mathrm{~cm}$ proximal blocked $90 \%$ of gamma activity from accumulating in L4 and L5 DRG. After injection of comparable amounts of $\left[{ }^{125} \mathrm{I}\right]$ cytochrome $\mathrm{C}$ or $\left[{ }^{125} \mathrm{I}\right]$ oxidized NGF, gamma activity in lumbar DRG was not significantly higher than background (Table I). These control experiments exclude diffusion along the nerve, hematogenous spread, and nonspecific uptake as spurious causes of labeling in DRG of experimental rats.

To determine the rate of transport of $\left[{ }^{125} \mathrm{I}\right] \mathrm{NGF}$ in the sciatic nerve, rats were sacrificed $4,8,12,18$, and $24 \mathrm{hr}$ after intraneural injection in the thigh (Fig. 2b). No activity reached L4 and L5 DRG in $4 \mathrm{hr}$; counts were maximal at 12 to $18 \mathrm{hr}$ and fell by $24 \mathrm{hr}$. Given that the injection site was $3.5 \mathrm{~cm}$ from the 14 ganglion and that $\left[{ }^{125}\right.$ I]NGF diffused 0.5 to $1.5 \mathrm{~cm}$ proximally, the rate of transport was estimated at 2.5 to $7.5 \mathrm{~mm} / \mathrm{hr}$ for the fastest particles.

In another group of rats, a dose-response curve was obtained by injecting different quantities $(0.1$ to $74 \mathrm{ng}$ in $1 \mu \mathrm{l})$ of $\left[{ }^{125} \mathrm{I}\right] \mathrm{NGF}$ into the sciatic nerve and counting activity in L4 and L5 DRG after $11 \mathrm{hr}$ (Fig. 2c). Double reciprocal analysis of data (inverse of accumulation versus inverse of injection) indicated a saturable process with maximal accumulation per DRG of $29 \mathrm{pg}(1.1 \mathrm{fmol})$ and half-maximal uptake at $4 \mathrm{ng}(0.2 \mathrm{pmol})$ (Fig. $2 d)$. The true maximal accumulation is, perhaps, slightly higher because accumulation was $38 \mathrm{pg}$ in one series of rats injected with freshly dialyzed $\left[{ }^{125} \mathrm{I}\right] \mathrm{NGF}$. The amounts of NGF injected were insufficient to study probable additional uptake at lower affinity (Dumas et al., 1979). 
1.

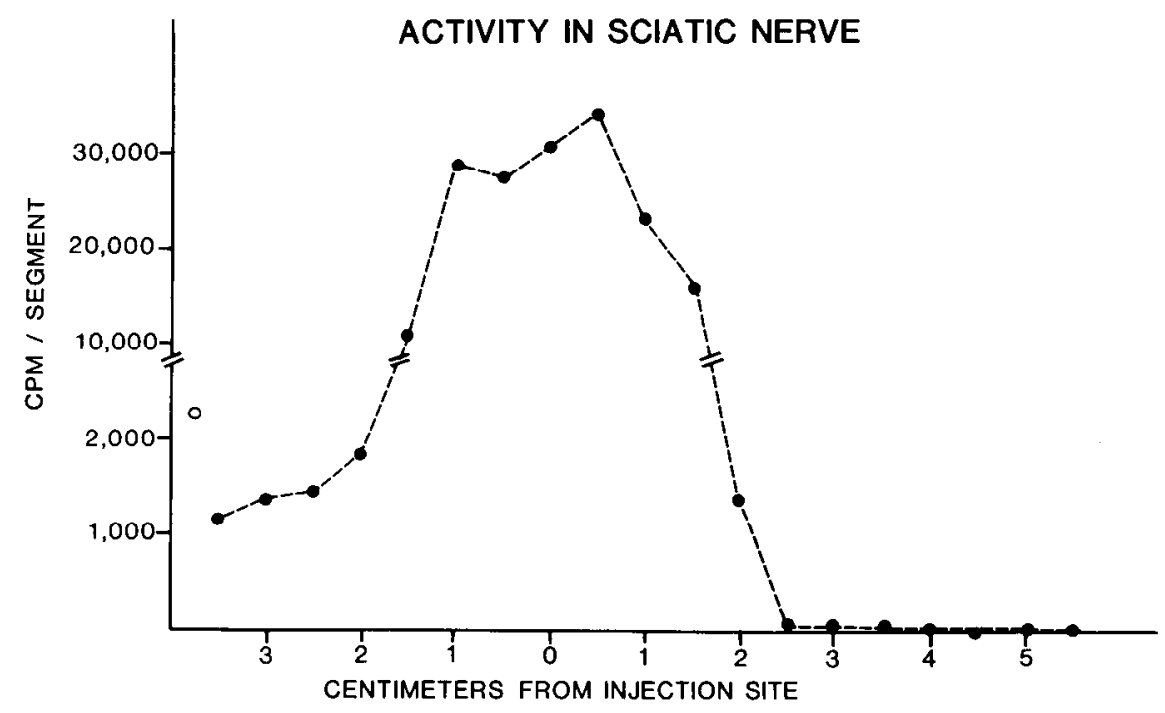

Figure 1. Activity in segments, $5 \mathrm{~mm}$ long, of the sciatic nerve $12 \mathrm{hr}$ after injection of $\left[{ }^{125} \mathrm{I}\right] \mathrm{NGF}(1 \mu \mathrm{l}, 8 \mathrm{ng}, 500,000 \mathrm{cpm})$ into nerve in upper thigh. mean value per segment in two injected nerves; $O$, mean total activity in $L 4$ and L5 DRG. Thirty-seven percent of injected activity was recovered in the nerve and two DRG at 12 hr. Very high counts near the site of injection indicate the extent of diffusion; negligible counts in distal segments show lack of anterograde axonal transport; moderate counts in proximal segments and DRG are compatible with retrograde axonal transport.

After SDS-polyacrylamide gel electrophoresis, $77 \%$ of the recovered gamma activity migrated in the penultimate slice before the front as did a standard molecule of molecular weight $=14,400$ ( $\alpha$-lactalbumin). This information is compatible with previous evidence that NGF is transported retrogradely in an intact form (Hendry et al., 1974; Stoeckel et al., 1975; Johnson et al., 1978; Dumas et al., 1979).

In radioautographs of $L 4$ and L5 DRG, label was concentrated in neurons rather than non-neuronal cells or the extracellular space. Neurons of all sizes were labeled and, in some ganglia, more than a third of neurons contained 10 or more grains.

Uptake from lumbar spinal cord. Very little $\left[{ }^{125} \mathrm{I}\right] \mathrm{NGF}$ diffused into L4 and L5 spinal roots after lumbar intraspinal injection. In one such rat, $10 \mathrm{hr}$ after injection, the total activity in a $1 \mathrm{~cm}$ segment of the spinal cord at the site of injection was $218,000 \mathrm{cpm}$, and the average activities in consecutive $5-\mathrm{mm}$ segments of the $\mathrm{L} 4$ and L5 roots were $1721,543,240,255$, and $386 \mathrm{cpm}$. Thus, injection of $\left[{ }^{125} I\right] N G F$ into the lumbar spinal cord did not result in a large pool of activity in the lumbar spinal roots.

After intraspinal injection, as after intraneural injection, $\left[{ }^{125} \mathrm{I}\right] \mathrm{NGF}$ was consistently recovered from $\mathrm{L} 4$ and L5 DRG (Fig. $3 a$ ). In radioautographs, activity was concentrated in neurons. Accumulation was prevented if dorsal roots were crushed or avulsed at the time of injection (Table I). Twelve hours after injection of $\left.{ }^{[25} \mathrm{I}\right]$ cytochrome $\mathrm{C}$, the mean activity in L4 and L5 DRG averaged $8 \mathrm{cpm}$ above background.

The time course of accumulation of $\left[{ }^{125} \mathrm{I}\right] \mathrm{NGF}$ in lum- bar DRG after injection into the lumbar spinal cord (Fig. $3 b$ ) showed insignificant activity at $4 \mathrm{hr}$, peak counts at $12 \mathrm{hr}$, and some loss from the ganglia by $24 \mathrm{hr}$. As the L4 and L5 dorsal roots are 2.5 to $3.0 \mathrm{~cm}$ long, these data are compatible with maximal retrograde axonal transport at 3.1 to $7.5 \mathrm{~mm} / \mathrm{hr}$.

A dose-response curve (Fig. $3 c$ ) and double reciprocal plotting of data (Fig. $3 d$ ) again suggested saturable uptake with maximal accumulation of $14 \mathrm{pg}(0.5 \mathrm{fmol}) /$ DRG and half-maximal uptake with $14 \mathrm{ng}(0.5 \mathrm{pmol})$.

Uptake from high spinal levels. In a total of 11 rats (Table II), $\left[{ }^{125} \mathrm{I}\right] \mathrm{NGF}$ from four preparations was injected into the dorsal columns and dorsal column nuclei at the craniocervical junction. Subsequently, mean accumulation per lumbar DRG was 0.5 to $1.3 \mathrm{pg}$ in the four groups. In radioautographs of DRG in one well labeled animal, approximately $6 \%$ of neurons were labeled (Fig. 4). Counts in lumbar DRG after cervical injection of [ $\left.{ }^{125} \mathrm{I}\right]$ cytochrome $\mathrm{C}$ did not exceed background.

Following injection of $\left.{ }^{[25} \mathrm{I}\right] \mathrm{NGF}$ into the midthoracic spinal cord (32 ng in $3 \mu \mathrm{l}$ ), the accumulation per lumbar DRG $(0.8 \pm 0.1 \mathrm{pg})$ was similar to that after cervical injection of the same batch of $\left[{ }^{125} \mathrm{I}\right] \mathrm{NGF}$. The uptake was unchanged by deliberate injury to the spinal cord immediately rostral to the site of injection.

\section{Discussion}

NGF uptake by peripheral axons. NGF receptors are deduced to be present along the course of normal sensory axons in the sciatic nerve because the intraneuronal accumulation of [ $\left.{ }^{125} I\right] N G F$ injected into the endoneurium cannot be entirely explained by diffusion to peripheral 
2a.

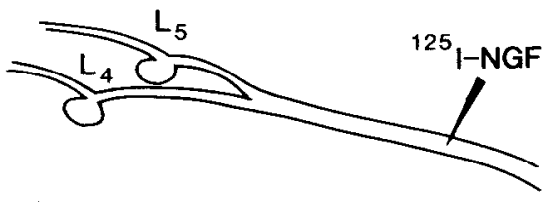

$2 b$.

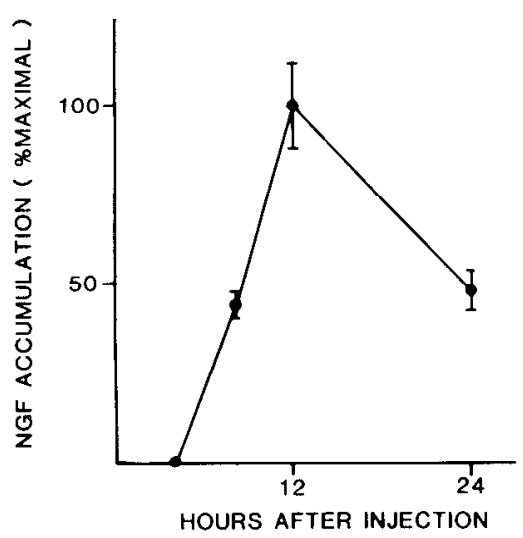

$2 \mathrm{c}$.

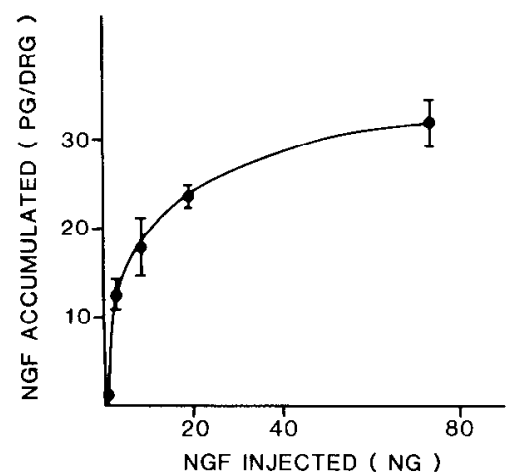

$2 d$.

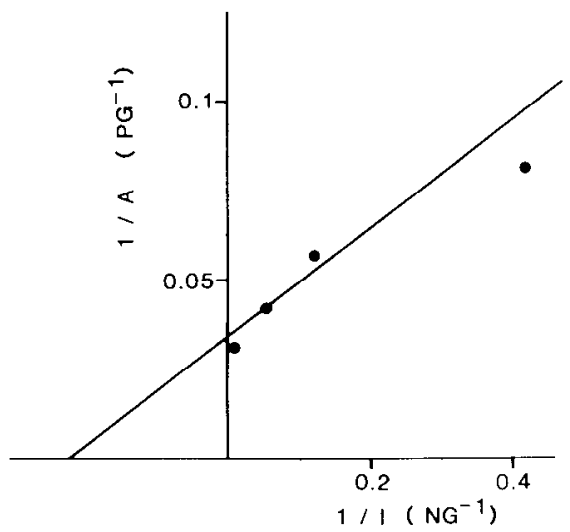

Figure 2. a, Diagram illustrating experiments in which $\left[{ }^{125} \mathrm{I}\right] \mathrm{NGF}$ was injected into the sciatic nerve in the upper thigh and gamma activity was subsequently counted in L4 and L5 DRG. $b$, Accumulation of NGF in L4 or L5 DRG of rats sacrificed 0 to $24 \mathrm{hr}$ after injection of $\left[{ }^{125} \mathrm{I}\right] \mathrm{NGF}(1 \mu \mathrm{l}, 11 \mathrm{ng})$ into sciatic nerve in upper thigh. The mean $\pm \mathrm{SEM}$ for 12 ganglia ( 6 nerves) is expressed as a percentage of the accumulation at $12 \mathrm{hr}$. c, Accumulation of NGF in L4 or L5 DRG of rats sacrificed $11 \mathrm{hr}$ after injection of 0.3 to $74 \mathrm{ng}$ of $\left[{ }^{125} \mathrm{I}\right] \mathrm{NGF}(1 \mu \mathrm{l})$ into sciatic nerve in upper thigh. A mixture of labeled and unlabeled NGF was used for the highest concentration; serial dilutions of $\left[{ }^{125} I\right] N G F$ were used for all other points. Data are the mean \pm SEM (picograms per DRG) for 12 to 16 ganglia and 6 to 8 nerves. $d$, Double reciprocal plot of data in $c$. The reciprocal of the $y$ intercept $=$ the maximal amount of $\left[{ }^{125} I\right] N G F$ accumulated per DRG by high affinity system $-29 \mathrm{pg}(1.1 \mathrm{fmol})$. The reciprocal of the $x$ intercept $=$ the amount of injected $\left[{ }^{125} \mathrm{I}\right] \mathrm{NGF}$ yielding half-maximal saturation $=4 \mathrm{ng}(0.2 \mathrm{pmol})$.

TABLE I

Comparison of mean accumulation per DRG in one experimental group and three control groups after intraneural injection, and in one experimental group and two control groups after intraspinal injection Activity in L4 and L5 DRG was counted 12 to $24 \mathrm{hr}$ after injection

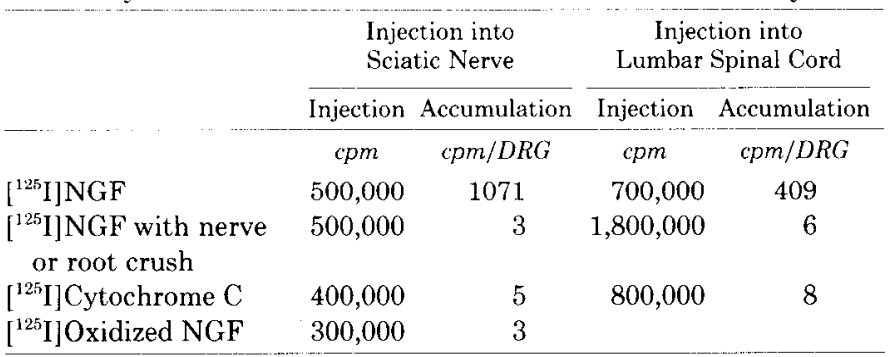

receptors or by injury of axons at the time of injection. Indeed, it was originally reported (Hendry et al., 1974), although not subsequently emphasized, that intact terminals are not necessary for NGF internalization by sympathetic axons. NGF receptors were specific in their recognition of injected molecules and in their distribution among types of axons. $\left[{ }^{125} \mathrm{I}\right]$ Cytochrome $\mathrm{C}$ and $\left[{ }^{125} \mathrm{I}\right]$ oxidized NGF were not taken up at high affinity as was $\left[{ }^{125} \mathrm{I}\right]$ NGF; somatic motor axons did not internalize and transport $\left[{ }^{125} \mathrm{I}\right] \mathrm{NGF}$ as did sensory axons (and, presumably, sympathetic axons). Although ${ }^{125} \mathrm{I} \mid \mathrm{NGF}$ accumulated in large and small neurons in DRG, it is not known whether axonal membrane on all dorsal root ganglion neurons is equally responsive to NGF. The maximal rate of retrograde axonal transport of NGF in sensory axons was found to be slightly slower than previously calculated (Stoeckel et al., 1975) but similar to that for NGF in sympathetic axons (Hendry et al., 1974) and for other proteins in general (Grafstein and Forman, 1980).

Quantitative considerations. The amounts of NGF accumulating in sensory ganglia after intraneural injection and in sympathetic ganglia after intraocular injection are similar, as are the amounts of injected NGF necessary 
3a.
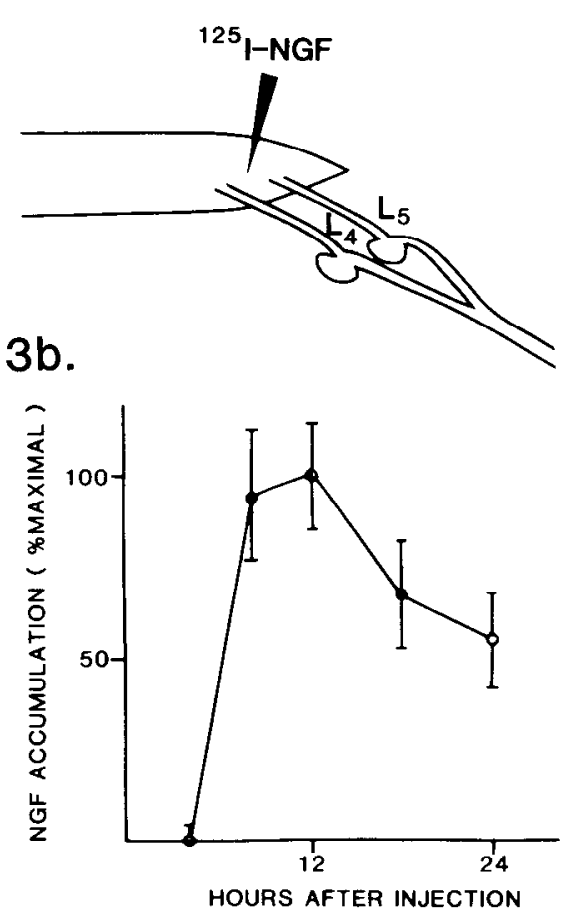

3c.
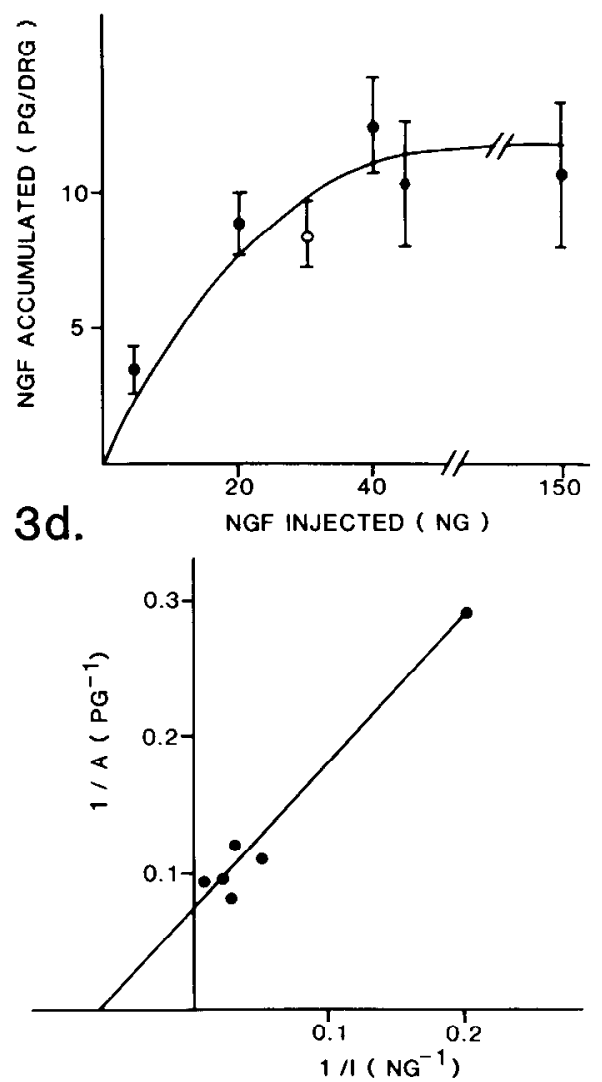

Figure 3. a, Diagram illustrating experiments in which $\left[{ }^{125} \mathrm{I}\right]$ NGF was injected into lumbar spinal cord and gamma activity was subsequently counted in L4 and L5 DRG. $b$, Accumulation of NGF in L4 or L5 DRG in rats sacrificed 0 to $24 \mathrm{hr}$ after injection of $\left[{ }^{125} \mathrm{I}\right] \mathrm{NGF}$ into the lumbar spinal cord. Two preparations of $\left.{ }^{125} \mathrm{I}\right] \mathrm{NGF}$ were injected: $\mathrm{O}, 40 \mathrm{ng}$ in $4 \mu \mathrm{l} ; \mathbf{O}, 100 \mathrm{ng}$ in $3 \mu \mathrm{l}$. The mean $\pm \mathrm{SEM}$ for 16 ganglia (4 rats) is expressed as a percentage of the accumulation at $12 \mathrm{hr} . c$, Accumulation of NGF in L4 or L5 DRG in rats sacrificed $12 \mathrm{hr}$ after injection of $\left[{ }^{125} \mathrm{I}\right]$ NGF $(4 \mu \mathrm{l})$ into the lumbar spinal cord. $O$, Three different batches of $\left[{ }^{125} \mathrm{I}\right]$ $\mathrm{NGF}$ were used. Data are the mean \pm SEM (picograms of $\left[{ }^{125} \mathrm{I}\right] \mathrm{NGF}$ per DRG) for 16 ganglia (4 rats). A mixture of labeled and unlabeled NGF was used for the highest concentration; serial dilutions of $\left[{ }^{125} \mathrm{I}\right]$ NGF were used for all other points. $d$, Double reciprocal plot of data in $c$. The reciprocal of the $y$ intercept $=$ the maximal amount of $\left.{ }^{125} \mathrm{I}\right] \mathrm{NGF}$ accumulated per DRG by high affinity system $=$ $14 \mathrm{pg}(0.5 \mathrm{fmol})$. The reciprocal of the $x$ intercept $=$ the amount of injected $\left[{ }^{125} \mathrm{I}\right]$ NGF yielding half-maximal saturation $=14 \mathrm{ng}(0.5 \mathrm{pmol})$.

TABLE II

Cervical injection of $\left[^{125} I\right] N G F$

Results of four experiments ( 11 rats) in which [ $\left.{ }^{125} \mathrm{I}\right] \mathrm{NGF}$ was injected into the dorsal columns and dorsal column nuclei at the bulbospinal junction. Gamma activity in L4 and L5 was consistently above background levels.

\begin{tabular}{|c|c|c|c|}
\hline \multicolumn{2}{|c|}{ Injection } & $\begin{array}{l}\text { Hours to } \\
\text { Sacrifice }\end{array}$ & Accumulation \\
\hline$n g$ & $\mu l$ & & $p g / D R G \pm S E M$ \\
\hline 20 & 2 & 18 & $0.6 \pm 0.1$ \\
\hline 32 & 3 & 24 & $0.6 \pm 0.1$ \\
\hline 42 & 2 & 24 & $0.8 \pm 0.1$ \\
\hline 53 & 2 & 24 & $1.3 \pm 0.2$ \\
\hline
\end{tabular}

for half-maximal uptake (Johnson et al., 1978). The maximal accumulation and half-saturation point of the dose-response curve are assumed to reflect the density and affinity of axonal receptors for NGF (Dumas et al., 1979). The density of receptors in the sciatic nerve can be very approximately estimated at $10,000 / \mathrm{mm}$ length of each sensory axon if it is assumed that $\left[{ }^{125} \mathrm{I}\right] \mathrm{NGF}$ reaching the L4 or L5 DRG is taken up by 6000 axons over a 10 -mm segment of nerve, that each receptor internalizes one molecule of NGF only, and that recycling of receptors is negligible during a few hours. The dissociation equilibrium constant $\left(K_{d}\right)$ of axonal receptors cannot be calculated precisely from these data because the concentration of $\left.{ }^{125} \mathrm{I}\right] \mathrm{NGF}$ at the axonal membrane after endoneurial injection is unknown. It remains to be proved that NGF receptors with $K_{d}$ in the order of $10^{-11} \mathrm{M}$ are present on adult rat axons as on embryonic chick neurons (Sutter et al., 1979; Riopelle et al., 1980).

The finding of NGF receptors along the course of peripheral sensory axons suggests that NGF released by endoneurial cells might have local paracrine effects. However, the amount of injected $\left[{ }^{125} \mathrm{I}\right] \mathrm{NGF}$ yielding halfsaturable uptake in sensory axons (4 ng) is two orders of 

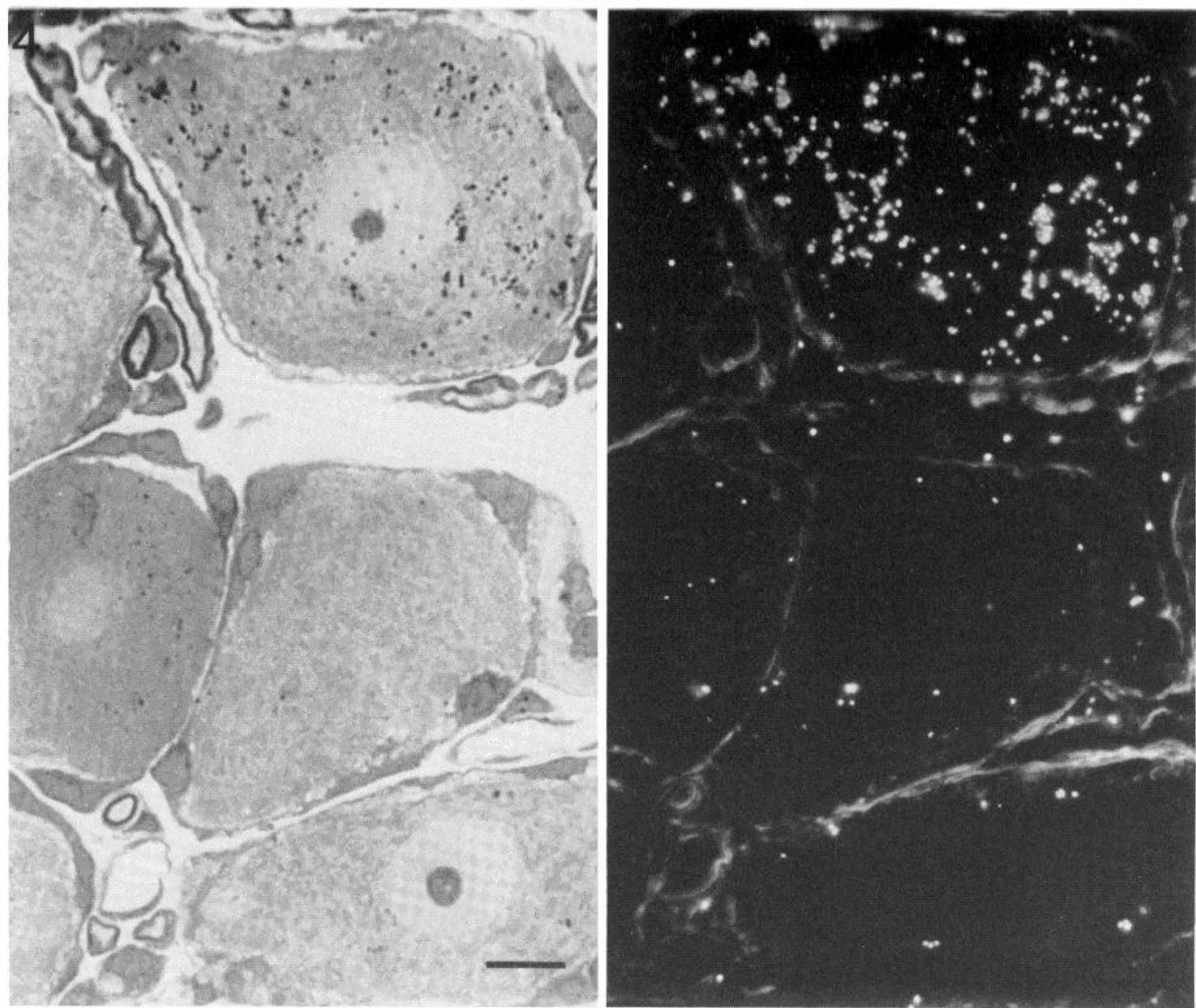

Figure 4. Light- and darkfield radioautographs of L5 DRG in a rat sacrificed $24 \mathrm{hr}$ after injection of $\left.{ }^{125} \mathrm{I}\right] \mathrm{NGF}(2 \mu \mathrm{l}, 53 \mathrm{ng}, 4.5$ $\times 10^{6} \mathrm{cpm}$ ) into dorsal column nuclei and high cervical dorsal columns. Labeling in one neuron is well above background level $($ scale bar $=10 \mu \mathrm{m})$.

magnitude greater than the estimated content of NGFlike activity per centimeter length of normal rat sciatic nerve (Ebendal and Richardson, 1983). Quantitative analysis of endogenous ligand-receptor interactions awaits knowledge of the distribution of NGF-like activity within the endoneurium and the deployment of NGF receptors on axonal membrane of nodal and internodal segments.

NGF uptake by spinal axons. Previous evidence that receptors for NGF are present within the central nervous system (Frazier et al., 1974; Schwab et al., 1979) is corroborated by the finding of labeled neurons in radioautographs of lumbar DRG after cervical injection of $\left[{ }^{125}\right.$ I]NGF (Fig. 4). In other words, ensheathment by Schwann cells is not a necessary condition for the manifestation of NGF receptors. The apparent difference in affinities of NGF uptake from the lumbar spinal cord and the sciatic nerve is probably due to a larger volume of diffusion in the spinal cord rather than to different dissociation equilibrium constants for spinal and peripheral receptors. Sites for NGF internalization could be on terminal or nonterminal regions of spinal axons, and their density per unit area of axon membrane in the spinal cord could be equal or less to that in peripheral nerves. The function of NGF receptors in the maintenance and regeneration (Richardson et al., 1982) of sensory axons in the spinal cord is unknown.

\section{References}

Beitz, A. J., and G. W. King (1976) An improved technique for the microinjection of horseradish peroxidase. Brain Res. 108: 175-179.

Burnham, P., C. Raiborn, and S. Varon (1972) Replacement of nerve-growth factor by ganglionic non-neuronal cells for the survival in vitro of dissociated ganglionic neurons. Proc. Natl. Acad. Sci. U. S. A. 69: 3556-3560.

Carbonetto, S., and R. W. Stach (1982) Localization of nerve growth factor bound to neurons growing nerve fibers in culture. Dev. Brain Res. 3: 463-473.

Chapman, C. A., B. E. C. Banks, C. A. Vernon, and J. M. Walker (1981) The isolation and characterisation of nerve growth factor from the prostate gland of the guinea-pig. Eur. J. Biochem. 115: 347-351.

Cohen, P., A. Sutter, G. Landreth, A. Zimmermann, and E. M. Shooter (1980) Oxidation of tryptophan-21 alters the biological activity and receptor binding characteristics of mouse nerve growth factor. J. Biol. Chem. 255: 2949-2954. 
Dumas, M., M. F. Schwah, and H. Thoenen (1979) Retrograde axonal tranaport of specific macromolecules as a tool for characterizing nerve terminal membranes. J. Neurobiol. 10: 179-197.

Ebendal, T., and P. M. Richardson (1983) Bioassay and ra= dioimmunoasary of $\mathrm{NGF}$-like activity in rat periphoral nerve; Soc. Neurosci. Abstr. $9: 839$

Frazier, W. A., L. F. Boyd, M. W. Pulliam, A. Szutowicz, and R. A. Bradshaw (1974) Properties and specificity of binding sites for ${ }^{125}$ I-nerve growth factor in embryonic heart and brain. J. Biol. Chem. 249: 5918-5923.

Goedert, M., K. Stoeckel, and U. Otten (1981) Biological importance of the retrograde axonal transport of nerve growth factor in sensory neurons. Proc. Natl. Acad. Sci. U. S. A. 78: $5895-5898$

Gorin, P. D., and E. M. Johnson (1979) Experimental autoimmune model of nerve growth factor deprivation: Effects on developing peripheral sympathetic and sensory neurons. Proc. Natl. Acad. Sci. U. S. A. 76: 5382-5386.

Gorin, P. D., and E. M. Johnson, Jr. (1980) Effects of longterm nerve growth factor deprivation on the nervous system of the adult rat: An experimental autoimmune approach. Brain Res. 198: 27-42.

Grafstein, B., and D. S. Forman (1980) Intracellular transport in neurons. Physiol. Rev. 60: 1167-1283.

Hendry, I. A., K. Stoeckel, H. Thoenen, and L. L. Iversen (1974) The retrograde axonal transport of nerve growth factor. Brain Res. 68: 103-121.

Johnson, E. M., Jr., R. Y. Andres, and R. A. Bradshaw (1978) Characterization of the retrograde transport of nerve growth factor (NGF) using high specific activity ${ }^{125}$ I-NGF. Brain Res. 150: 319-331.

Kessler, J. A., and I. B. Black (1980) Nerve growth factor stimulates the development of substance $P$ in sensory ganglia. Proc. Natl. Acad. Sci. U. S. A. 77: 649-652.

Kim, S. U., R. Hogue-Angeletti, and N. K. Gonatas (1979) Localization of nerve growth factor receptors in sympathetic neurons cultured in vitro. Brain Res. 168: 602-608.

Laemmli, U. K. (1970) Cleavage of structural proteins during the assembly of the head of bacteriophage T4. Nature 227: $680-685$.

Mobley, W. C., A. Schenker, and E. M. Shooter (1976) Characterization and isolation of proteolytically modified nerve growth factor. Biochemiatry 15: $5543-5551$.

Otten, $\overline{\mathrm{U}}$, and $\mathrm{H}$. P. Lorez (1983) Nervẹ growth factor increaseses substance $\overline{\mathbf{P}}$, cholecystokinin and vasoactive intestinal poly= peptide immunoreactivities in primary sensory neurones of newborn rats. Neurosci. Lett. 34: 153-158.

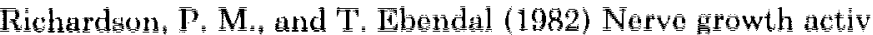
ities in rat peripheral nerve. Brân Res. 246: 57-64.

Richardson, P. M., U. M. McGuinñness, and A. J. Aguayo (1982) Peripheral nerve autografts to the rat spinal cord: Studies with axonal tracing methods. Brain Res. 237: 147-162.

Riopelle, R. J., and D. A. Cameron (1981) Neurite growth promoting factors of embryonic chick-ontogeny, regional distribution and characteristics. J. Neurobiol. 12: 175-186.

Kiopelle, R. J., M. Klearman, and A. Sutter (1980) Nerve growth factor receptors: Analysis of the interaction of $\beta \mathrm{NGF}$ with membranes of chick embryo dorsal root ganglia. Brain Res 199: 63-77.

Riopelle, R. J., R. J. Boegman, and D. A. Cameron (1981) Peripheral nerve contains heterogeneous growth factors that support sensory neurons in vitro. Neurosci. Lett. 25: $311-$ 316.

Rohrer, H., and Y. -A. Barde (1982) Presence and disappearance of nerve growth factor receptors on sensory neurons in culture. Dev. Biol. 89: 309-315.

Schwab, M. E., U. Otten, Y. Agid, and H. Thoenen (1979) Nerve growth factor (NGF) in the rat CNS: Absence of specific retrograde axonal transport and tyrosine hydroxylase induction in locus coeruleus and substantia nigra. Brain Res. 168: 473-483.

Schwartz, J. P., J. Pearson, and E. M. Johnson (1982) Effect of exposure to anti-NGF on sensory neurons of adult rats and guinea pigs. Brain Res. 244: 378-381.

Stoeckel, K., M. Schwab, and H. Thoenen (1975) Specificity of retrograde transport of nerve growth factor (NGF) in sensory neurons: A biochemical and morphological study. Brain Res. 89: $1-14$.

Sutter, A., R. J. Riopelle, R. M. Harris-Warrick, and E. M. Shooter (1979) Nerve growth factor receptors: Characterization of two distinct classes of binding sites on chick embryo sensory ganglia cells. J. Biol. Chem. 254: 5972-5982.

Varon, S. S., and R. P. Bunge (1978) Trophic mechanisms in the peripheral nervous system. Annu. Rev. Neurosci. 1:327361 . 